\title{
Effects of intercropping on temperate grasses canopy architecture and nutritive
}

\section{profile}

\section{Efeitos do consórcio na arquitetura do dossel forrageiro e perfill nutricional de gramíneas de clima} temperado

Efecto de los cultivos intercalados en la arquitectura del dossel forrajero y el perfil nutricional de las gramíneas templadas

Sarah Maria Hoppen

ORCID: https://orcid.org/0000-0001-7531-8484 Western State University of Parana, Brazil E-mail: sarah.hoppen@hotmail.com

Marcela Abbado Neres

ORCID: https://orcid.org/0000-0003-3221-4030 Western State University of Parana, Brazil E-mail: mabaneres@gmail.com

Paulo Sérgio Rabello de Oliveira ORCID: https://orcid.org/0000-0002-0478-1006

Western State University of Parana, Brazil E-mail: rabello.oliveira@hotmail.com

Elir de Oliveira

ORCID: https://orcid.org/0000-0003-2935-7604 Agronomic Institute of Parana, Brazil E-mail: drelir@gmail.com

Caroline Daiane Nath

ORCID: https://orcid.org/0000-0002-6996-5201

Western State University of Parana, Brazil E-mail: karolynedayane@hotmail.com

\begin{abstract}
This paper aimed to evaluate the impact of intercropping between oats and triticale species, over three defoliation cycles. The experiment occurred in two winters in a row, and was in split-plot randomized complete blocks design (20 plots) with five species combination, four blocks and three defoliations. The main plots were the species combination: black oat (Avena strigosa cv. IAPAR 61) - BO, white oat (Avena sativa cv. IPR Emerald) - WO, triticale (X Triticosecale Wittmack cv. Tpolo 981) - T; and the intercropping: black oat + triticale - BOT, and white oat + triticale - WOT. The sub-plots were the three defoliations cycles initially scheduled to be every 28 days. The intercropping between oats and triticale did not affect the accumulated dry matter yield (DM), but it also improved the pastures, as an increase on crude protein content (CP) (about $1.85 \%$ greater in WOT than WO; and $2.7 \%$ greater in BOT than BO). The number of leaves was also increased by the intercropping, from 4.2 (WO) and 3.7 (BO) to 7.6 (WOT) and 7.2 (BOT) leaves per main stem. Over the defoliation cycles, the maximum average of growth rate $\left(2.72 \mathrm{t} \mathrm{DM} \mathrm{ha}^{-1}{ }^{\circ} \mathrm{Cd}^{-1}\right)$, tiller per plant (10 tillers plant $\left.^{-1}\right)$ and main tiller height $(53.2 \mathrm{~cm})$ were unanimously observed at third defoliation. The changes observed did not reduced the nutritional quality of the pastures, therefore both are highly indicated to these conditions.
\end{abstract}

Keywords: Avena sativa L. IPR Emerald; Avena strigosa Schreb IAPAR 61; Competition; Tiller density; $X$ Triticosecale Wittmack Tpolo 981.

\section{Resumo}

O objetivo deste trabalho foi avaliar o impacto do consórcio entre aveias e triticale, ao longo de três ciclos de pastejo. O experimento ocorreu em dois invernos seguidos, em delineamento em blocos casualizados com parcelas subdivididas no tempo (20 parcelas) com cinco combinações de espécies, quatro blocos e três pastejos. As parcelas principais foram as combinações de espécies: aveia preta (Avena strigosa cv. IAPAR 61) - BO, aveia branca (Avena sativa cv. IPR Esmeralda) - WO, triticale (X Triticosecale Wittmack cv. Tpolo 981) - T; os consórcios aveia preta + triticale $-\mathrm{BOT}$, e aveia branca + triticale - WOT. As subparcelas foram os três ciclos de pastejo inicialmente agendados para ocorrerem a cada 28 dias. O consórcio entre aveias e triticale não afetou a produção de matéria seca (MS), mas aumentou a concentração de proteína bruta (PB) (cerca de 1.85\% superior em WOT comparado a WO; e 2.72\% superior em BOT do que BO). O número de folhas vivas também foi aumentado, de 4.2 (WO) e 3.7 (BO) para 7.6 (WOT) e 7.2 (BOT) folhas no perfilho principal. Durante os ciclos de pastejo, a média máxima de taxa de crescimento $\left(2.72 \mathrm{t} \mathrm{DM} \mathrm{ha}^{-1}{ }^{\circ} \mathrm{Cd}\right.$ 
$\left.{ }^{1}\right)$, perfilhos por planta $\left(10\right.$ perfilhos planta $\left.^{-1}\right)$ e altura do perfilho principal $(53.2 \mathrm{~cm})$ foram unanimemente obtidos na terceira desfolhação. As mudanças observadas não reduziram a qualidade nutricional das pastagens, sendo assim ambos consórcios são indicados para estas condições.

Palavras-chave: Avena sativa L. IPR Esmeralda; Avena strigosa Schreb IAPAR 61; Competição; Densidade de perfilhos; X Triticosecale Wittmack Tpolo 981.

\section{Resumen}

Este artículo tuvo como objetivo evaluar el impacto de los cultivos intercalados entre especies de avena y triticale, durante tres ciclos de defoliación. El experimento se llevó a cabo en dos inviernos consecutivos, en un diseño de bloques al azar con parcelas divididas en el tiempo (20 parcelas) con cinco combinaciones de especies, cuatro bloques y tres de pastoreo. Las principales parcelas fueron combinaciones de especies: avena negra (Avena strigosa cv. IAPAR 61) - BO, avena blanca (Avena sativa cv. IPR Esmeralda) - WO, triticale (X Triticosecale Wittmack cv. Tpolo 981) - T; los consorcios avena negra + triticale - BOT, y avena blanca + triticale - WOT. Las subparcelas fueron los tres ciclos de pastoreo inicialmente programados para ocurrir cada 28 días. El cultivo intercalado entre avena y triticale no afectó la producción de materia seca (MS), pero aumentó la concentración de proteína cruda (CP) (aproximadamente $1.85 \%$ más alta en WOT en comparación con WO; y 2.72\% más alta en BOT que BO). También se incrementó el número de hojas, de 4,2 (WO) y 3,7 (BO) a 7,6 (WOT) y 7,2 (BOT) hojas en la macolla principal. Durante los ciclos de pastoreo, la tasa máxima promedio de crecimiento $\left(2,72 \mathrm{t} \mathrm{MS} \mathrm{ha}^{-1}{ }^{\circ} \mathrm{Cd}^{-1}\right)$, macollos por planta $\left(10\right.$ macollos planta $\left.{ }^{-1}\right)$ y altura de macollos principales $(53,2 \mathrm{~cm})$ se obtuvieron por unanimidad en la tercera defoliación. Los cambios observados no redujeron la calidad nutricional de los pastos, por lo que ambos consorcios están indicados para estas condiciones.

Palabras clave: Avena sativa L. IPR Esmeralda; Avena strigosa Schreb IAPAR 61; Competência; Densidad de macollos; X Triticosecale Wittmack Tpolo 981.

\section{Introduction}

The temperate grasses are used to fill the winter gap produced by the dormancy of Cynodon spp. and as soil winter cover in crop-livestock systems. The main characteristic of these species is frost resistance (Poirier et al., 2012), very common in this area from May to August.

Although known as highly nutritive feed, these grasses have a lower yield compared with tropical ones, which leads producers to reduce the area of their cultivation, and the use of silage and grains supplementation to animals, etc. To optimize the cultivation area, some researchers have been trying to enhance the productivity of temperate grasses by mixture different genotypes and species (Carvalho et al., 2011; Duchini et al., 2016; Ferrazza et al., 2013).

The intercropping of species with different growth patterns and rates can be synchronized to increase the persistence (Carvalho et al., 2011) of high digestible fibre in the field, stimulate the leaf emergence and elongation rates, promote the yield in different horizons in the canopy (Duchini et al., 2016), increase the crude protein levels of the pasture and produce a maximum of $9 \mathrm{t} \mathrm{DM} \mathrm{ha}^{-1}$ (Ferrazza et al., 2013). The most used intercropping in South Brazil is between black oat (Avena sativa L.) + ryegrass (Lolium multiflorum Lam.)

However, it also can increase the leaf senescence and stem elongation when the species are not in balance (Duchini et al., 2016), which may result in a decrease of nutritional quality, depending on the damage level. The process of genotype choice is essential to achieve the producer objective, associated with the right management to optimize the soil use.

The objective of this paper was to determine the effects of intercropping white oat IPR Emerald and black oat IAPAR 61 with triticale Tpolo 981, by evaluating the productivity, canopy structure and nutritive quality of the canopy compared with their monocrop over three defoliations cycles.

\section{Methodology}

The experiment was established at the Experimental Farm of Western Parana State University - UNIOESTE, campus

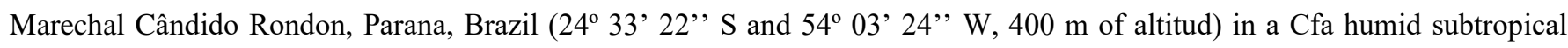
weather, with $22{ }^{\circ} \mathrm{C}$ as the highest average temperature and $18{ }^{\circ} \mathrm{C}$ as the lowest average temperature, with frequent frosts over winter (Bhering \& Santos, 2008). The rainfall and temperature data were obtained from the local weather station situated $100 \mathrm{~m}$ 
far from the field experiment (Figure 1), from which the accumulated thermal-time $\left({ }^{\circ} \mathrm{Cd}\right)$ was counted using the "threshold broken-stick" method (Moot et al., 2001), adapted for temperate grasses, with basal temperature $\left(\mathrm{T}_{\mathrm{b}}\right)$ equals to $1{ }^{\circ} \mathrm{C}$. The experiment was performed over the winters of two consecutive years.

Figure 1. Mean temperature and accumulate rainfall in Marechal Cândido Rondon, Paraná, Brazil, during the winter of Years 1 and 2 .

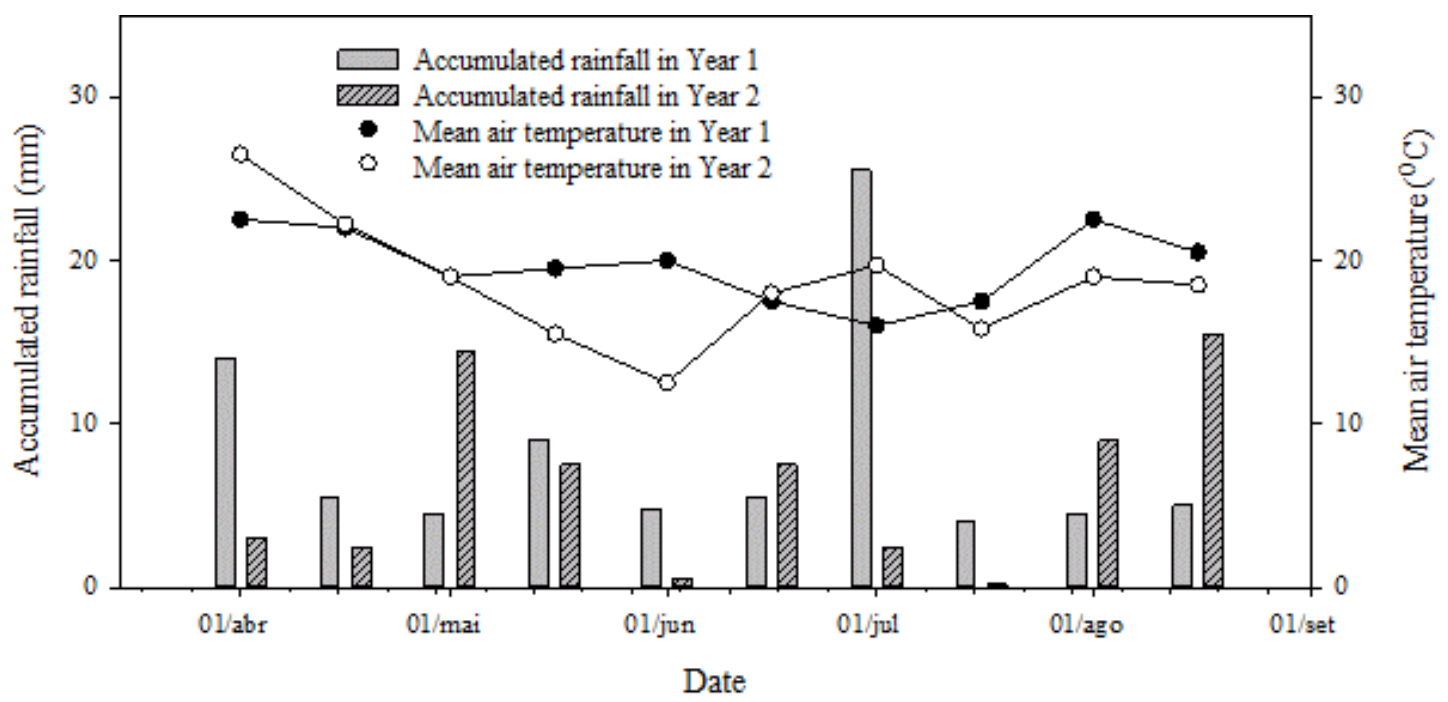

Source: Authors.

The area ( $0.10 \mathrm{ha})$ had been cultivated in a crop-livestock system with corn and soybeans during the spring/summer and temperate grasses in the cold seasons for the past eight years. The soil is classified as Latosoil Red Eutoferric (EMBRAPA, 2006) and initially presented $\mathrm{pH}\left(\mathrm{CaCl}_{2}\right)$ of $4.95,21.87 \mathrm{~g} \mathrm{dm}^{-3}$ of organic matter, $0.32 \mathrm{cmol}_{\mathrm{c}} \mathrm{dm}^{-3}$ of K, $2.30 \mathrm{cmol}_{\mathrm{c}} \mathrm{dm}^{-3} \mathrm{of} \mathrm{Ca}^{2+}$, $2.30 \mathrm{cmol}_{\mathrm{c}} \mathrm{dm}^{-3}$ of $\mathrm{Mg}^{2+}, 5.50 \mathrm{cmol}_{\mathrm{c}} \mathrm{dm}^{-3}$ of $\mathrm{Al}+\mathrm{H}, 0.15 \mathrm{cmol}_{\mathrm{c}} \mathrm{dm}^{-3}$ of $\mathrm{Al}^{3+}, 38.08 \mathrm{mg} \mathrm{dm}^{-3}$ of $\mathrm{P}, 1.60 \mathrm{mg} \mathrm{dm}^{-3}$ of $\mathrm{Zn}$ and 3.87 $\mathrm{mg} \mathrm{dm}{ }^{-3}$ of $\mathrm{Al}$, at $20 \mathrm{~cm}$ of depth.

The experiment was in split-plot randomized complete blocks design $\left(20\right.$ plots of $\left.52.8 \mathrm{~m}^{2}\right)$ with five species combination, four blocks and three defoliations. The main plots were the species combination: black oat (Avena strigosa cv. IAPAR 61) (60 kg seed ha $\left.{ }^{-1}\right)-\mathrm{BO}$, white oat (Avena sativa cv. IPR Emerald) (60 kg seed ha $\left.{ }^{-1}\right)-\mathrm{WO}$, triticale (X Triticosecale Wittmack cv. Tpolo 981) $(140 \mathrm{~kg}$ seed ha-1 $)-\mathrm{T}$; and the intercropping: black oat $\left(50 \mathrm{~kg} \mathrm{ha}^{-1}\right)+$ triticale $\left(120 \mathrm{~kg} \mathrm{seed} \mathrm{ha}^{-1}\right)-$ BOT, and white oat $\left(50 \mathrm{~kg} \mathrm{ha}^{-1}\right)+$ triticale $(120 \mathrm{~kg}$ seed ha-1) - WOT. The sub-plots were the defoliations cycles initially scheduled to be every 28 days, as performed by farmers in this region.

The species were sown in April of 2015 using no-tillage seeding, with $17 \mathrm{~cm}$ between rows and 3-5 $\mathrm{cm}$ of seed depth. The plants emerged about seven days later. An establishment period of 25 days was settled, followed by a nitrogen (N) application (60 $\left.\mathrm{kg} \mathrm{N} \mathrm{ha}^{-1}\right)$, like urea. After the establishment phase the cycle period (28 days) started to be counted, but due to the weather conditions took about 28,32 and 38 days for the $1^{\text {st }}, 2^{\text {nd }}$ and $3^{\text {rd }}$ regrowth cycles, respectively.

The structural and phenological measurements were performed at the end of each regrowth cycle. The number of tillers and plants were counted using a frame of $0.25 \mathrm{~m}^{2}$ twice per plot randomly chosen, where all tillers and plants were counted by species. A non-marked tiller morphometric evaluation adapted from Carrère et al. (1997) was performed by taken 10 tillers of each species, randomly chosen, and the height from soil to the curve of the highest leaf, or the top of inflorescence when present, number of live and dead leaves and stem diameter (using a digital caliper below the first node) were measured. The SPAD index was measured in 10 random mature leaves of each species, by a chlorophyllometer (SPAD-502, Minolta, Osaka, Japan). 
Biomass yield was measured with the use of a $0.5 \mathrm{~m}^{2}$ frame randomly chosen per plot, where all the content was handcut. A straw residue of $8-12 \mathrm{~cm}$ remained to consider only the available forage to animals, once this was the output height. Right after the measurements, the defoliations were performed by dairy cows using the "put-and-take" technique (Mott \& Lucas, 1952) until the output height was achieved. From the slope between biomass yield and accumulated thermal-time data, the values of linear growth rate were obtained.

The biomass samples were dried in a forced-air oven at $60^{\circ} \mathrm{C}$ for $72 \mathrm{~h}$ to determine biomass yield dry matter (DM). The dried samples were ground in a knife mill to $\sim 1 \mathrm{~mm}$ of particle size, and then analyzed for neutral detergent fibre $\left(\mathrm{NDF}_{\mathrm{pa}}\right)$, acid detergent fibre (ADF) and lignin in 72\% sulphuric acid (Van Soest et al., 1980), and crude protein (CP, micro Kjeldahl) (AOAC, 1995).

Attributes were analyzed separately by year to determine the interaction between treatments and defoliations according to the following model:

$Y_{i j k}=\mu+T_{i}+B_{j}+e_{i j}+d_{k}+\delta_{i k}+e_{i j k}$

Where $Y_{i j k}$ is the $i^{\text {th }}$ species combination value in the $j^{\text {th }}$ block at the $\mathrm{k}^{\text {th }}$ defoliation, having $\mu$ as overall model average, $T_{i}$ being the treatment fixed effect, $B_{j}$ the block fixed effect and $e_{i j}$ the experimental error between treatment and block. The $d_{k}$ represents the defoliations as a random effect, while $\delta_{\mathrm{ik}}$ represents the interaction between treatment and defoliation, with $\mathrm{e}_{\mathrm{ijk}}$ as the experimental error between the $\mathrm{i}^{\text {th }}$ treatment value, the $\mathrm{j}^{\text {th }}$ block value and the $\mathrm{k}^{\text {th }}$ defoliation value. Means were compared by Tukey's honestly significant difference test $(\alpha=0.05)$ by ANOVA. Statistical analyses were performed using the software SAS ${ }^{\circ}$ On Demand. The graphics were produced using SigmaPlot Software®, version 14.0.

\section{Results}

The accumulated dry matter $(\mathrm{DM})$ yield differs $(\mathrm{P}<0.05)$ among systems only in Year 2 (Table 1$)$. The systems with oat in a single crop had higher $(\mathrm{P}<0.05)$ yield than triticale, with no differences to the intercropping. The greatest $(\mathrm{P}<0.05) \mathrm{DM}$ yield occurred in the third cut when plants entered in reproductive stage. The growth rate maintained (P>0.05) 1.64 and $2.45 \mathrm{t}^{\mathrm{DM}} \mathrm{ha}^{-}$ ${ }^{1} \mathrm{Cd}^{-1}$ in Years 1 and 2. The increase of temperatures from the second defoliation on allowed the plants to increase $(\mathrm{P}<0.05)$ the growth rate and, probably, enter on the reproductive stage. 
Table 1. Accumulated dry matter yield $\left(\mathrm{t} \mathrm{DM} \mathrm{ha}{ }^{-1}\right)$, linear growth rate $\left(\mathrm{t} \mathrm{DM} \mathrm{ha}^{-1} \mathrm{Cd}^{-1}\right)$, number of tillers (tillers $\left.\mathrm{m}^{-2}\right)$ and number of live leaves of white oat IPR Emerald (WO), black oat IAPAR 61 (BO) and triticale Tpolo 981 (T) in single crop or intercropping (WOT and BOT) defoliated three times over two years at Marechal Cândido Rondon, Parana, Brazil.

\begin{tabular}{|c|c|c|c|c|c|c|c|c|}
\hline & \multicolumn{2}{|c|}{$\begin{array}{l}\text { Accumulated DM yield } \\
\left(\mathrm{t} \text { DM ha }{ }^{-1}\right)\end{array}$} & \multicolumn{2}{|c|}{$\begin{array}{c}\text { Growth rate } \\
\left(\mathrm{t} \mathrm{DM} \mathrm{ha}^{-1}{ }^{\circ} \mathrm{Cd}^{-1}\right)\end{array}$} & \multicolumn{2}{|c|}{ Tiller $\mathrm{m}^{-2}$} & \multicolumn{2}{|c|}{ Number of live leaves } \\
\hline & Year 1 & Year 2 & Year 1 & Year 2 & Year 1 & Year 2 & Year 1 & Year 2 \\
\hline WO & 3.70 & $2.93 \mathrm{a}$ & 1.90 & 2.59 & $218.17 \mathrm{a}$ & $330.09 \mathrm{ab}$ & $3.99 b$ & $4.44 b$ \\
\hline WOT & 4.04 & $2.70 \mathrm{ab}$ & 1.87 & 2.83 & $203.70 b$ & $370.74 \mathrm{ab}$ & $7.27 \mathrm{a}$ & $7.96 \mathrm{a}$ \\
\hline $\mathrm{BO}$ & 2.97 & $2.84 \mathrm{a}$ & 1.26 & 2.15 & $253.83 \mathrm{a}$ & $396.72 \mathrm{ab}$ & $3.63 b$ & $3.83 \mathrm{c}$ \\
\hline BOT & 3.64 & $2.14 \mathrm{ab}$ & 1.77 & 2.68 & $262.73 a$ & $457.03 \mathrm{a}$ & $6.87 \mathrm{a}$ & $7.64 \mathrm{a}$ \\
\hline $\mathrm{T}$ & 2.87 & $1.91 b$ & 1.41 & 2.00 & $265.06 \mathrm{a}$ & $252.98 b$ & $3.44 b$ & $3.85 \mathrm{c}$ \\
\hline SE & 281.6 & 167.8 & 0.15 & 0.18 & 14.08 & 36.61 & 0.31 & 0.09 \\
\hline $\mathrm{P}$ & 0.0435 & 0.0002 & 0.0015 & 0.48 & 0.66 & 0.56 & $<0.0001$ & $<0.0001$ \\
\hline $1^{\text {st }}$ & $0.58 \mathrm{c}$ & $0.84 \mathrm{c}$ & $0.80 \mathrm{~b}$ & $1.13 \mathrm{~b}$ & $290.36 \mathrm{a}$ & $267.85 b$ & $5.97 a$ & $5.49 b$ \\
\hline $2^{\text {nd }}$ & $1.90 \mathrm{~b}$ & $1.43 b$ & $2.03 \mathrm{a}$ & $3.29 \mathrm{a}$ & $284.57 \mathrm{a}$ & $410.62 \mathrm{a}$ & $4.60 \mathrm{~b}$ & $5.24 \mathrm{c}$ \\
\hline $3^{\text {rd }}$ & $3.44 \mathrm{a}$ & $2.50 \mathrm{a}$ & $2.26 \mathrm{a}$ & $3.19 \mathrm{a}$ & $147.16 b$ & $406.05 a$ & $4.54 b$ & $5.89 \mathrm{a}$ \\
\hline SE & 50.99 & 72.12 & 0.09 & 0.12 & 10.90 & 28.35 & 0.24 & 0.07 \\
\hline $\mathrm{P}$ & $<0.0001$ & $<0.0001$ & $<0.0001$ & $<0.0001$ & $<0.0001$ & 0.0012 & $<0.0001$ & $<0.0001$ \\
\hline \multicolumn{9}{|c|}{ Species combination $\mathrm{x}$ defoliation } \\
\hline $\mathrm{P}$ & 0.85 & 0.73 & 0.97 & 0.64 & 0.02 & 0.13 & 0.82 & 0.03 \\
\hline
\end{tabular}

Averages followed by the same letter in column did not differ by Tukey's test $(\alpha=0.05)$. Source: Authors.

The phenology results presented contrary patterns between the years. There was a sharp reduction in tiller population, from 284 tillers $\mathrm{m}^{-2}$ in the second regrowth cycle, to 147 tillers $\mathrm{m}^{-2}$ on the third cycle of Year 1 . However, Year 2 showed an average of 408 tiller $\mathrm{m}^{-2}$ in a similar period, with no differences $(\mathrm{P}>0.05)$ among species systems. As the number of tillers is dependent on the number of leaves, a similar pattern was obtained over the defoliations, a reduction $(\mathrm{P}<0.05)$ in $\mathrm{Year} 1$ and a gradual increase $(\mathrm{P}<0.05)$ in Year 2. However, the number of live leaves was higher $(\mathrm{P}<0.05)$ in intercropped systems, and in Year 2 it was even lower $(\mathrm{P}<0.05)$ for black oat and triticale in a single crop, compared with the other systems.

Another important phenology variable tested was the stem diameter, and it presented interaction between species and the number of defoliations $(\mathrm{P}<0.05)$ in both years (Figure 2$)$. In general, the triticale presented thinner $(\mathrm{P}<0.05)$ stems, mainly compared to white oat, whereas the black oat ranged between the two extremes. Two interesting points to bring up are 1) the thicker $(\mathrm{P}<0.05)$ stem of black oat intercropped with triticale at second defoliation (about $0.07 \mathrm{~mm}$ greater than the single crop); and 2) the reduction of oats stem diameter from $>3.8 \mathrm{~mm}$ in the second to a maximum of $3.5 \mathrm{~mm}$ in the third defoliation. 
Figure 2. Stem diameter (mm) of white oat (WO), black oat (BO) and triticale (T) in single crop or intercropping and defoliated three sequential times over two winters at Marechal Cândido Rondon, Parana, Brazil.

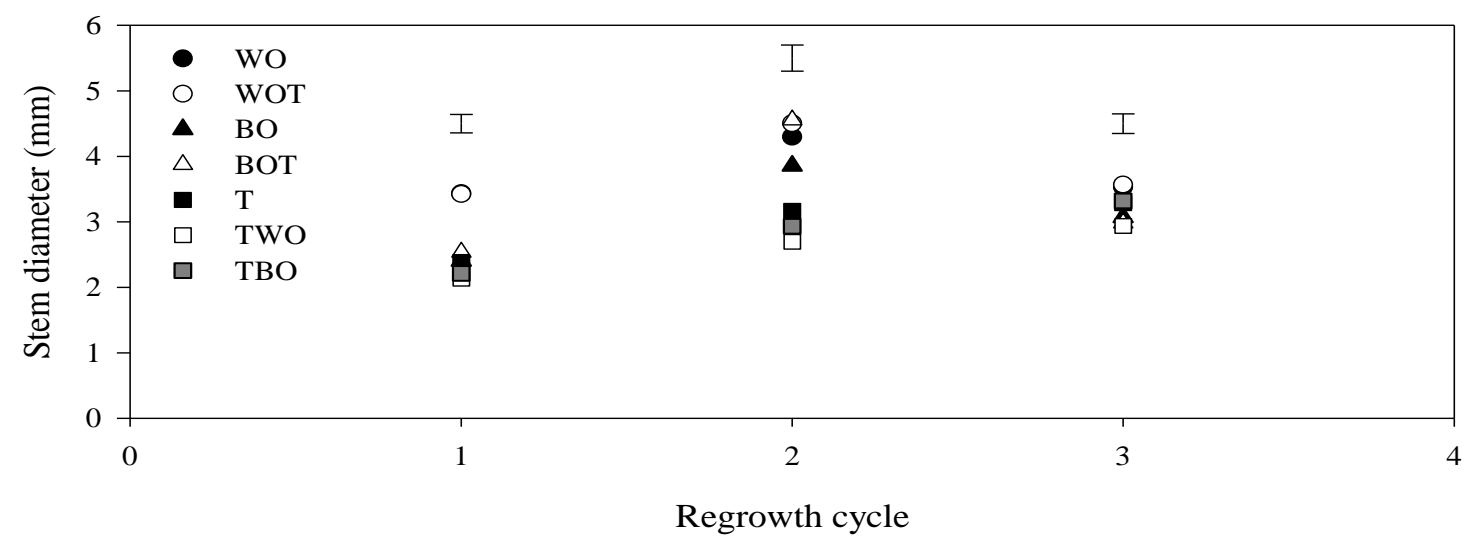

WOT represents the results of white oat intercropped to triticale; BOT represents the results of black oat intercropped to triticale; TWO and TBO represent triticale results intercropped to white oat and black oat, respectively. Error bars represent standard error when differences were noticed by Tukey's test $(\alpha=0.05)$. Source: Authors.

Contrary to tiller $\mathrm{m}^{-2}$, the number of tillers per plant increased over the defoliations in both years, from 4.8 and 6.4 tiller plant $^{-1}$ at the first defoliation to 9.2 and 10.6 tillers plant ${ }^{-1}$ at the third defoliation (Table 2). There were no differences $(\mathrm{P}>0.05)$ among genotypes and systems, with total averages of 7.1 and 9.1 tillers plant ${ }^{-1}$, irrespective of Years 1 and 2.

The black oat main tiller height was affected $(\mathrm{P}<0.05)$ by the intercropping, which caused the increase of the main tiller compared to its single crop. Among different species, there were differences $(\mathrm{P}<0.05)$ as the white oat IPR Emerald is naturally taller than the Triticale Tpolo 981. The increase in tiller height at the third defoliation reinforces the entering of plants on the reproductive stage, when the temperature was favourable to it. With the increase in tiller height, the number of senescent leaves also increased $(\mathrm{P}<0.05)$ by the defoliations, and achieved 2.3 and 1.6 leaves plant ${ }^{-1}$ at the end of both experiments.

The SPAD index presented differences $(\mathrm{P}<0.05)$ among species in Year 2, with the triticale as the highest values, independent of the system (> 60), and by the defoliations it fluctuated with a pattern of increase from $\sim 40$ to $\sim 50$. As a nondestructive indication of nitrogen $(\mathrm{N})$ content, the SPAD index obtained a similar response of crude protein $(\mathrm{CP})$. It was noticed by the greater $(\mathrm{P}<0.05)$ concentration of $\mathrm{CP}$ on triticale systems (Table 3$)$.

Even with the greatest CP content, the triticale CP yield (0.57 and $0.29 \mathrm{t} \mathrm{CP} \mathrm{ha}^{-1}$, at Years 1 and 2) was lower than the WO at the single crop (0.58 and $0.41 \mathrm{t} \mathrm{CP} \mathrm{ha}^{-1}$, respectively), due to the lower shoot yield obtained in those treatments (Table 3). The black oat IAPAR 61 had the CP yield increased when intercropped with triticale $\mathrm{T}$ at Year 1 (from 0.55 to $0.68 \mathrm{t} \mathrm{CP} \mathrm{ha}^{-}$ ${ }^{1}$, for BO and BOT treatments), a fact that has not occurred in Year 2 when the maximum was $0.37 \mathrm{t} \mathrm{CP} \mathrm{ha}^{-1}$ achieved by BO.

The fibre variables (NDF and ADF) exalted the tallest plants of white oat IPR Emerald and shown the greatest $(\mathrm{P}<0.05)$ values of 38\% (NDF of WOT at Year 1) and 18.6\% (ADF of WO at Year 1). Over the defoliations, as the plants entered on reproductive stage, the fibre content was increased $(\mathrm{P}<0.05)$, to a maximum of $40 \%$ of NDF, $17.2 \%$ of ADF, and $5.6 \%$ of lignin. 
Table 2. Phenological characteristics of white oat IPR Emerald (WO), black oat IAPAR 61 (BO) and triticale Tpolo 981 (T) in single crop and intercropped, defoliated sequential times over two years at Marechal Cândido Rondon, Parana, Brazil.

\begin{tabular}{|c|c|c|c|c|c|c|c|c|}
\hline & \multicolumn{2}{|c|}{ Tiller plant $^{-1}$} & \multicolumn{2}{|c|}{ Main tiller height $(\mathrm{cm})$} & \multicolumn{2}{|c|}{ Number of dead leaves } & \multicolumn{2}{|c|}{ SPAD index } \\
\hline & Year 1 & Year 2 & Year 1 & Year 2 & Year 1 & Year 2 & Year 1 & Year 2 \\
\hline WO & 8.26 & 8.06 & $55.26 \mathrm{a}$ & 42.87 & 1.23 & 0.68 & 46.25 & $47.41 \mathrm{~b}$ \\
\hline WOT & 6.56 & 6.82 & $56.58 \mathrm{a}$ & 43.07 & 1.52 & 0.62 & 48.77 & $48.76 \mathrm{~b}$ \\
\hline $\mathrm{BO}$ & 9.56 & 10.79 & $39.24 b$ & 43.08 & 0.89 & 0.57 & 44.18 & $50.51 \mathrm{~b}$ \\
\hline BOT & 7.35 & 8.72 & $49.43 \mathrm{a}$ & 35.53 & 1.44 & 0.72 & 44.20 & $50.56 \mathrm{~b}$ \\
\hline $\mathrm{T}$ & 8.10 & 12.77 & $33.42 \mathrm{bc}$ & 37.35 & 1.19 & 0.60 & 50.92 & $67.82 \mathrm{a}$ \\
\hline TWO & 4.45 & 7.93 & $28.34 \mathrm{c}$ & 34.77 & 1.37 & 0.64 & 46.97 & $65.34 \mathrm{a}$ \\
\hline TBO & 5.67 & 8.90 & $26.19 \mathrm{c}$ & 35.94 & 1.46 & 0.62 & 53.72 & $63.63 \mathrm{a}$ \\
\hline SE & 0.62 & 0.68 & 2.03 & 3.78 & 0.22 & 0.05 & 1.36 & 2.28 \\
\hline $\mathrm{P}$ & 0.14 & 0.82 & 0.0002 & 0.41 & 0.60 & 0.09 & 0.24 & 0.0255 \\
\hline $1^{\text {st }}$ & $4.82 \mathrm{c}$ & $6.43 b$ & $32.43 \mathrm{c}$ & $27.25 b$ & $0.11 \mathrm{c}$ & $0.06 \mathrm{c}$ & - & $49.24 \mathrm{c}$ \\
\hline $2^{\text {nd }}$ & $7.32 \mathrm{~b}$ & $10.35 \mathrm{a}$ & $40.62 b$ & $33.67 b$ & $1.48 \mathrm{~b}$ & $0.20 \mathrm{~b}$ & $43.04 \mathrm{~b}$ & $64.30 \mathrm{a}$ \\
\hline $3^{\text {rd }}$ & $9.22 \mathrm{a}$ & $10.65 \mathrm{a}$ & $50.57 \mathrm{a}$ & $55.91 \mathrm{a}$ & $2.31 \mathrm{a}$ & $1.64 \mathrm{a}$ & $52.67 \mathrm{a}$ & $55.33 b$ \\
\hline SE & 0.42 & 0.45 & 1.33 & 2.48 & 0.14 & 0.03 & 0.72 & 1.49 \\
\hline $\mathrm{P}$ & $<0.0001$ & $<0.0001$ & $<0.0001$ & $<0.0001$ & $<0.0001$ & $<0.0001$ & $<0.0001$ & $<0.0001$ \\
\hline \multicolumn{9}{|c|}{ Species combination $\mathrm{x}$ defoliation } \\
\hline SE & 1.08 & 1.18 & 3.51 & 6.56 & 0.39 & 0.09 & 1.92 & 3.94 \\
\hline $\mathrm{P}$ & 0.25 & 0.90 & 0.13 & 0.56 & 0.95 & 0.80 & 0.41 & 0.08 \\
\hline
\end{tabular}

WOT represents the results of white oat intercropped to triticale; BOT represents the results of black oat intercropped to triticale; TWO and TBO represent triticale results intercropped to white oat and black oat, respectively. SE: standard error. Averages followed by similar letter in column did not differ by Tukey's test $(\alpha=0.05)$. Source: Authors.

\section{Discussion}

This study aimed to compare the morphological plasticity of intercropped grasses and its impact on dry matter yield and nutritional profile. We also accessed the effects of continuous defoliations on these plants through the winter and vegetativereproductive stages.

The white oat IPR Emerald proved to be more $(\mathrm{P}<0.05)$ productive than the black oat IAPAR 61 and the triticale Tpolo 981, by its highest $(\mathrm{P}<0.05)$ and thickest $(\mathrm{P}<0.05)$ stems. In addition, its precocity, that allowed the earlier defoliation with almost $1.0 \mathrm{t} \mathrm{DM} \mathrm{ha}{ }^{-1}$ at 42 days after emergence (DAE). The results are still lower than the obtained by Demétrio et al. (2012), but those authors evaluated the temperate grasses over the spring, in greater photoperiod and temperatures. Oliveira et al. (2015) achieved the $5.8 \mathrm{t} \mathrm{DM} \mathrm{ha}^{-1}$ year $^{-1}$ when intercropped white oat IPR Emerald with triticale Tpolo 981. It may imply the low tolerance of these species to soil aluminium content (Al) that reduces the development of the roots and, consequently, the regrowth plant ability.

The low DM yield, which hardly exceeded 4 t DM ha ${ }^{-1}$ year ${ }^{-1}$, might be a reflex of seeding date. Ferrazza et al. (2013) and Pin et al. (2011) indicate that seeding of temperate grasses in Southwest of Parana is not economically worthy when performed after the second half of April, once long-cycled plants as black oat IAPAR 61 can express the whole potential and supply the demand of feed in the off-season. As the regrowth cycles in this experiment were settled by time, not canopy characteristics, it influenced a lower production linked to self-thinning resulted from a turnover within the canopy (Pin et al., 2011; Duchini et al., 2018). 
Table 3. Nutritional values of white oat IPR Emerald (WO), black oat IAPAR 61 (BO) and triticale Tpolo 981 (T) in single crop and intercropped (WOT and BOT, respectively to the oats), defoliated three sequential times over two years at Marechal Cândido Rondon, Parana, Brazil.

\begin{tabular}{|c|c|c|c|c|c|c|c|c|}
\hline & \multicolumn{2}{|c|}{$\mathrm{CP}(\%)$} & \multicolumn{2}{|c|}{$\operatorname{NDF}(\%)$} & \multicolumn{2}{|c|}{$\operatorname{ADF}(\%)$} & \multicolumn{2}{|c|}{ Lignin (\%) } \\
\hline & Year 1 & Year 2 & Year 1 & Year 2 & Year 1 & Year 2 & Year 1 & Year 2 \\
\hline WO & $15.6 \mathrm{c}$ & $14.1 \mathrm{bc}$ & $37.6 \mathrm{a}$ & 16.2 & $18.6 \mathrm{a}$ & $11.2 \mathrm{a}$ & 2.0 & $4.7 b$ \\
\hline WOT & $16.5 \mathrm{bc}$ & $16.9 \mathrm{a}$ & $38.0 \mathrm{a}$ & 15.9 & $18.2 \mathrm{ab}$ & $11.4 \mathrm{a}$ & 1.8 & $4.7 b$ \\
\hline $\mathrm{BO}$ & $18.5 \mathrm{ab}$ & $13.2 \mathrm{c}$ & $34.0 \mathrm{~b}$ & 13.8 & $16.5 \mathrm{c}$ & $10.1 b$ & 1.8 & $5.7 \mathrm{a}$ \\
\hline $\mathrm{BOT}$ & $18.8 \mathrm{ab}$ & $15.9 \mathrm{ab}$ & $30.6 b c$ & 15.0 & $15.4 b c$ & $9.8 \mathrm{bc}$ & 1.8 & $5.5 \mathrm{ab}$ \\
\hline $\mathrm{T}$ & $19.9 \mathrm{a}$ & $15.3 \mathrm{abc}$ & $30.1 \mathrm{c}$ & 11.3 & $15.1 \mathrm{c}$ & $9.1 \mathrm{c}$ & 2.0 & $5.8 \mathrm{a}$ \\
\hline SE & 0.64 & 0.59 & 0.78 & 1.14 & 0.46 & 0.22 & 0.07 & 0.19 \\
\hline $\mathrm{P}$ & 0.06 & 0.15 & 0.0008 & 0.87 & 0.0001 & 0.0007 & 0.96 & 0.0087 \\
\hline $1^{\mathrm{st}}$ & $19.3 \mathrm{a}$ & $15.6 \mathrm{a}$ & $29.8 c$ & 13.9 & 16.7 & $9.4 \mathrm{c}$ & $1.94 \mathrm{a}$ & $5.3 a$ \\
\hline $2^{\text {nd }}$ & $19.1 \mathrm{a}$ & $14.1 \mathrm{~b}$ & $32.6 b$ & 14.4 & 17.2 & $10.1 \mathrm{~b}$ & $1.73 b$ & $5.6 \mathrm{a}$ \\
\hline $3^{\text {rd }}$ & $15.0 \mathrm{~b}$ & $16.7 \mathrm{a}$ & $40.0 \mathrm{a}$ & 15.9 & 16.5 & $11.7 \mathrm{a}$ & $2.02 \mathrm{a}$ & $4.7 b$ \\
\hline SE & 0.42 & 0.39 & 0.51 & 0.75 & 0.30 & 0.14 & 0.05 & 0.13 \\
\hline $\mathrm{P}$ & $<0.0001$ & $<0.0001$ & $<0.0001$ & 0.16 & 0.29 & $<0.0001$ & $<0.0001$ & $<0.0001$ \\
\hline \multicolumn{9}{|c|}{ Species combination $\mathrm{x}$ defoliation } \\
\hline SE & 1.12 & 1.03 & 1.35 & 1.98 & 0.81 & 0.38 & 0.12 & 0.33 \\
\hline $\mathrm{P}$ & 0.81 & 0.0003 & 0.17 & 0.0309 & 0.95 & 0.41 & 0.29 & 0.94 \\
\hline
\end{tabular}

SE: standard error. Averages followed by similar letter in column did not differ by Tukey’s test $(\alpha=0.05)$. Source: Authors.

White oats are known for higher canopies compared to other temperate grasses (Neres et al., 2012), which could imply greater light interception by the top canopy and shading on the lower leaves. However, the number of dead leaves and tillering results express the WO balance within the canopy, with no differences between a single crop and intercropping. The adjustment between tiller height, tiller density and stem diameter corroborates Sbrissia et al. (2018) results and indicates that in WO canopies the DM yield is more dependent on tiller weight than tiller population, contrary to triticale and black oat swards. On the other hand, Ducati et al. (2015) obtained greater tiller density (771 tillers $\mathrm{m}^{-2}$ of black oat IAPAR 61), but with lower number of live leaves (average of 2.15), which suggests another via to balance the canopy and keep the tiller size/density.

The growth rate responded to defoliation stimuli, increasing with positive photoperiod and flowering. The aerial biomass removal of grasses, mainly when it involves the apical meristem, causes an increase in basal tiller emission. These basal tillers tend to be shorter than the main tillers, as long as thinner and work as a balance between tiller size/density (Duchini et al., 2013). In this case, as the DM yield increased with it, the balance was positive and caused no loss to the canopy. On the contrary, the regular removal increased the leaves emission at Year 2, and the digestible fibre content.

The use of different growth pattern plants can optimize not only the horizontal space but also the vertical profile, with a greater number of leaves in different canopy horizons (Zhu et al., 2016). For that, the triticale is highlighted by its shorter height but greater photosynthetic capacity, proved by the SPAD index (Silva et al., 2013; Sim et al., 2015), which means the same production ability in a lower light environment. The triticale leaf angle also participated in this process, which allowed the plants to increase the light interception (Zhu et al., 2016).

The higher tiller density in the intercropping BOT appeared to have forced the black oat to increase their stems in second defoliation, a natural process to searchlight mainly in canopies with more than one growth pattern (Dordas \& Lithourgidis, 2011). This plasticity can imply nutritional quality reduction by the leaf:stem ratio changing (Castagnara et al. 2010), but in this case, 
it increased the $\mathrm{CP}$ yield without affecting the fibre and lignin content, and also the number of live leaves. According to Baxevanos et al. (2017) the high density, and the mixture of genotypes, is essential to force plants to express their whole production capacity. Without this light competition, the plants have a suitable situation at lower levels and find no difficulty to survive, but the boundaries must be defined to not reduce the nutritive quality.

A reduction on tiller $\mathrm{m}^{-2}$ within the defoliations in Year 1 (significant interaction, $\mathrm{P}=0.02$ ), is associated with a drought period right after the second defoliation (Figure 1). Australian temperate grasses have shown tiller population reduction with a decrease in water availability (Assuero \& Tognetti, 2010; Poirier et al., 2012), which is associated with specific leaf area (SLA) reduction in the meantime (Wellstein et al., 2017) and causes the early collapse of the canopy. Nevertheless, Duchini et al. (2018) suggested that this tillering reduction is a dormancy process in most sensitive plants, and, in a further adequate environment, they can recover and return to increase the tillering.

As seen in Year 2, a minimum post-defoliation water supply can avoid these low results. In that year the increase of the tiller population over the defoliations was supported by the continued crescent of black oat and triticale tillering, the most perennial species (Ferrazza et al., 2013). The intercropping WOT showed a synchronized pattern, the association of an early cycle plant (WO) and a perennial one (T) (Oliveira et al., 2015) where the persistence can be optimized and guarantee feed through the winter.

The $\mathrm{CP}$ achieved a maximum of $21.8 \%$ of DM for $\mathrm{T}$ at the first defoliation in Year 1, whereas the oats ranged between $12 \%$ (WO at $3^{\text {rd }}$ defoliation in Year 1) and $21.2 \%$ of DM (BO at $2^{\text {nd }}$ defoliation in Year 1). These results are much smaller than Neres et al. (2012) that obtained $24 \%$ and $19.6 \%$ at $1^{\text {st }}$ and $3^{\text {rd }}$ defoliations, respectively. Nevertheless, similar to those reported by Ducati et al. (2015) between 9.33 and $26.6 \%$ of DM. In that situation the authors found that, the intercropping between black oat and birdsfoot can cause the reduction of $\mathrm{CP}$ content over the time by the more intense competition for light. The NDF and $\mathrm{ADF}$ are also lower than reported in that paper, however, the lignin content is coherent (minimum of 2.9 and maximum of $6.3 \%$ of DM). The similar lignin results may indicate that the plants in this experiment entered in reproductive stage at first (WO) and third regrowth cycles. The former due to its precocity (Oliveira et al., 2015), the latter is a result of all treatments led to flowering by the drought stress in that stage (Poirier et al., 2012). In Year 2, the gradual crescent of lignin content was similar to the expressed in Neres et al. (2012) reports, which still characterized the results as from high nutritional quality grasses.

\section{Conclusion}

The intercropping between white oat IPR Emerald + triticale Tpolo 981 was effective to improve the different canopy horizons by the number of live leaves and the nutritional profile, with the increase in crude protein concentration.

The intercropping between black oat IAPAR $61+$ triticale Tpolo 981 increased the dry matter yield compared with a single triticale crop. It also increased the crude protein content, tiller population and number of live leaves, in comparison with the black oat in a single-use.

The SPAD index associated with the number of live leaves proved the high efficiency of triticale Tpolo 981 to produce with a lower light interception

In future studies, the persistence of these treatments shall be studied over the spring, to determine the longevity of the systems and comprehend the full cycle of these plants intercropped.

\section{Acknowledgments}

To CAPES, by the financial support to the first author conduct the research. To UNIOESTE, that made the area available to the experiment. To IAPAR, that donated the seeds of forages to be evaluated. 


\section{References}

AOAC. (1995). Official methods of analysis of the Association of the Analytical Chemists. (16a ed.).

Assuero, S. G., \& Tognetti, J.A. (2010). Tillering regulation by endogenous and environmental factors ad its agriculture management. The Americas Journal of Plat Science and Biotechnology. 4(1), 35-48. http://www.globalsciencebooks.info/Online/GSBOnline/images/2010/AmJPSB_4(SI1)/AmJPSB_4(SI1)3548o.pdf.

Baxevanos, D. et al. (2017). Cultivar competitiveness in pea-oat intercrops under Mediterranean conditions. Field Crops Research. 214, 94-103. https://www.sciencedirect.com/science/article/abs/pii/S037842901730638X. 10.1016/j.fcr.2017.08.024.

Bhering, S. B. \& Santos, H. G. (2008). Mapa de solos do Estado do Paraná: legenda atualizada. EMBRAPA/IAPAR. 74p.

Carvalho, P. C. F. et al. (2011). Forrageiras de Clima Temperado. In: Fonseca, D. M.; Martuscello, J. A. (Org.). Plantas Forrageiras. Viçosa: UFV, 1, $494-537$.

Carrère, P., Louault, F. \& Soussana, J. F. (1997). Tissue turnovers within grass - clover mixed sward grazed by sheep. Methodology for calculating growth, senescence and intake fluxes. Journal of Applied Ecology. 34, 333-348. https://www.jstor.org/stable/2404880

Castagnara, D. D. et al. (2010). Características estruturais e produtivas da aveia preta Comum em cinco idades de rebrota na região Oeste do Paraná. Cultivando o Saber.3(2), 116-129. https://www.fag.edu.br/upload/revista/cultivando_o_saber/59274dc4b7dc4.pdf.

Demétrio, J. V. et al. (2012). Produção de biomassa de cultivares de aveia sob diferentes manejos de corte. Pesquisa Agropecuária Tropical. 42(2), 198-205. https://www.revistas.ufg.br/pat/article/view/16217.

Dordas, C. A. \& Lithourgidis, A. (2011). S. Growth, yield and nitrogen performance of faba bean intercrops with oat ad triticale at varying seeding ratios. Grass and Forage. 66(4), 569-577.https://onlinelibrary.wiley.com/doi/abs/10.1111/j.1365-2494.2011.00814.x. 10.1111/j.1365-2494.2011.00814.x.

Ducati, C., et al. (2015). Forage potential of black oat Iapar 61 alone or in association with birdsfoot trefoil. Ciencia y Investigación Agraria. 42(3), 341-351. https://dialnet.unirioja.es/servlet/articulo?codigo=5316064. 10.4067/S0718-16202015000300003.

Duchini, P. G. et al. (2013). Tiller size/density compensation in temperate climate grasses grown in monoculture or in intercropping systems under intermittent grazing. Grass and Forage Science.69(4). https://www.researchgate.net/publication/259549405_Tiller_sizedensity_compensation_in_ttemperat_climate_ grasses_grown_in_monoculture_or_in_intercropping_systems_under_interintermi_grazing. Doi:10.1111/gfs.12095

Duchini, P. G. et al. (2016). Intercropping black oat (Avena strigosa) and annual ryegrass (Lolium multiflorum) can increase pasture leaf production compared with their monocultures. Crop \& Pasture Science. 67, 574-581. https://www.publish.csiro.au/ CP/CP15170. 10.1071/CP15170

Duchini, P. G. et al. (2018). Changes in tillering dynamics of intercropped black oat and annual ryegrass ensure a stable sward. Experimental Agriculture. 54(6), 931-942. https://www.cambridge.org/core/journals/experimental-agriculture/article/abs/changes-in-tillering-dynamics-of-intercropped-black-oat-and-annualryegrass-ensure-a-stable sward/BAD2A146B673E36E94DB26C698E86C25. 10.1017/S0014479717000503.

EMBRAPA. (2006). Sistema Brasileiro de Classificação de Solos. (2a ed). EMBRAPA-SPI.

Ferrazza, J. M. et al. (2013). Produção de forrageiras anuais de inverno em diferentes épocas de semeadura. Revista Ciência Agronômica. 44(2), 378-389. http://ccarevista.ufc.br/seer/index.php/ccarevista/article/viewFile/1762/813. 10.1590/S1806-66902013000200022

Mott, G.O. \& Lucas, H.L. (1952). The design, conduct and interpretation of grazing trials in cultivated and improved pastures. In: International Grassland Congress. 6, Pasadena. Proceedings. Pasadena: Pennsylvania State College, 1380-1385.

Moot, D.J., Robertson, M.J. \& Pollock, K.M. (2001). Validation of the APSIM-Lucerne model for phenological development in a cool-temperate climate. In: Proceedings..., Hobart, Tasmania.

Neres, M.A. et al. (2012). IPR 126 white oat forage potential under free growth, cutting and grazing at two management heights. Revista Brasileira de Zootecnia. 41(4), 889-897. https://www.scielo.br/pdf/rbz/v41n4/09.pdf. 10.1590/S1516-35982012000400009

Oliveira, G. C. et al. (2015). Integração lavoura-pecuária com aveia consorciada. Cultivando o Saber. 8(2), 104-113. https://cultivandosaber.fag.edu.br/ index.php/cultivando/article/view/643/568.

Pin, E.A. et al. (2011). Forage production dynamics of winter annual grasses sown on different dates. Revista Brasileira de Zootecnia. 40(3), 509-517. https://www.scielo.br/pdf/rbz/v40n3/07.pdf. 10.1590/S1516-35982011000300007

Pin, E. A. et al. (2013)

Poirier, M., Durand, J. L., \& Volaire, F. (2012). Persistence and production of perennial grasses under water deficit and extreme temperatures: importance of intraspecific vs. interspecific variability. Global Changing Biology. 18(12). https://onlinelibrary.wiley.com/doi/10.1111/j.1365-2486.2012.02800.x. $10.1111 / \mathrm{j} .1365-2486.2012 .02800 . x$

Sbrissia, A. F. et al. (2018). Defoliation strategies in pastures submitted to intermittent stocking method: underlying mechanisms buffering forage accumulation over a range of grazing height. Crop Science. 58(2), 145-154. https://acsess.onlinelibrary.wiley.com/doi/full/10.2135/cropsci2017.07.0447. 10.2135/cropsci2017.07.0447

Silva, M. A. et al. (2013). Photosynthetic capacity and water use efficiency in sugarcane genotypes subjected to water deficit during early growth phase. Brazilian Archives of Biology and Technology. 56(5), 735-748. https://www.scielo.br/j/babt/a/jzBcSWs3K7jHj67wKXpQxNn/?format=pdf\&lang=en. 10.1590/S151689132013000500004 . 
Research, Society and Development, v. 10, n. 11, e401101119831, 2021

(CC BY 4.0) | ISSN 2525-3409 | DOI: http://dx.doi.org/10.33448/rsd-v10i11.19831

Sim, C. C. et al. (2015). Rapid determination of leaf chlorophyll concentration, photosynthetic activity and NK concentration of Elaies guineensis via correlated SPAD-502 chlorophyll index. Asian Journal of Agricultural Research. 9(3), 132-138. https://www.cabdirect.org/cabdirect/abstract/20153261041. 10.3923/ajar.2015.132.138.

Van Soest, P. J. et al. (1980). Methods for dietary fiber, neutral detergent fiber and non-starch polysaccharides in relation to animal nutrition. Journal Dairy Science. 74, 3583-3597. https://www.sciencedirect.com/science/article/pii/S0022030291785512. 10.3168/jds.S0022-0302(91)78551-2

Wellstein, C. et al. (2017). Effects of extreme drought on specific leaf area of grassland species: a meta-analysis of experimental studies in temperate and subMediterranean systems. Global Changing Biology. 23(6), 2473-2481. https://www.onlinelibrary.wiley.com/doi/abs/10.1111/gcb.13662. 10.1111/gcb.13662.

Zhu, J. et al. (2016). High productivity of wheat intercropped with maize is associated with plant architectural responses. Annals of Applied Biology. 168(3), 357-372. https://onlinelibrary.wiley.com/doi/abs/10.1111/aab.12268. 10.1111/aab.12268. 